\title{
Requirements for screening and confirmatory methods for the detection and quantification of marine biotoxins in end-product and official control
}

\author{
Philipp Hess ${ }^{1, *}$
}

\author{
${ }^{1}$ Ifremer, Centre de Nantes, Département Environnement, Microbiologie et Phycotoxines, Rue de l'île d'Yeu, \\ 44311 Nantes, Cedex 03, France \\ *: Corresponding author : P. Hess, Tel. : intl. + 2403742 57, Fax.: intl. + 2403740 26, email address : \\ philipp.hess@ifremer.fr
}

\begin{abstract}
:
An overview is given of the biological origin of phycotoxins, as well as their chemical characteristics. Major poisoning types are described and examples of poisoning events are given to illustrate the importance of the phenomenon to both shellfish consumers and the shellfish producing industry. The characteristics of phycotoxins as natural products, the lack of predictability of their occurrence, economic drivers and the freshness of shellfish consumed in many countries result in a number of requirements for methods to be used in the efficient detection of these compounds. Subsequently, the performance of mouse bioassays and mass spectrometry as detection tools are compared for examples from Irish and French monitoring programmes to assess the usefulness of qualitative and quantitative tools in official control, and their fitness for purpose compared with the requirements. The final part of the paper critically reviews methods available for the end-product and official control of shellfish toxins and their use in screening and confirmatory approaches in monitoring. Recent expert consultations on the methodology for phycotoxins at European and global level are summarised and recommendations are made for future progress in this area.
\end{abstract}

Keywords: Bioanalytical methods - Bioassays - Mass spectrometry - Liquid chromatography Biological samples 


\section{Introduction}

Shellfish toxins are produced by micro-algae which are consumed by bivalve molluscs as part of their natural diet. Thus, toxins are accumulated actively by shellfish, and concentrated in the hepatopancreas of bivalves. Although for many toxins the producing algae are now known (Table 1), the causative relationship has not always been clear and often required many years of intense study. Examples of such studies are the confirmation of Protoceratium reticulatum as a causative organism of Yessotoxin $(\mathrm{YTX})^{1}$, or the discovery of Azadinium spinosum as a producer of Azaspiracid (AZA) $)^{2,3}$.

As marine biotoxins are naturally produced compounds, many enzymatic systems in nature are capable of metabolising them. This characteristic puts them in contrast to man-made compounds such as polychlorinated biphenyls (PCBs) and pesticides many of which are very stable compounds for which nature has no metabolic processes foreseen. Similar to PCBs, dioxins or polycyclic hydrocarbons, most groups of marine toxins have also many analogues. Thus, between naturally produced analogues and metabolites of these, marine biotoxins constitute a vast array of bioactive chemicals. From a natural products or biosynthesis point of view, phycotoxins belong to several classes including amino acids (domoic acid), alkaloids (saxitoxin and tetrodotoxin) and polyketides (all others). Their molecular weight typically ranges between 300 to 1500 Dalton; therefore, algal toxins are often referred to as small molecules. Nevertheless, some compound groups such as palytoxins (PITXs) and maitotoxins (MTXs) are very sizeable molecules of 2678 and 3422 Dalton, respectively. MTX has been reported as the largest non-proteinaceous natural toxin. The chemical nature and molecular size classification distinguish phycotoxins from the very large group of venoms from snakes, spiders or cone snails which are typically very potent mixtures of proteinaceous toxins. Table 2 gives an overview of some chemical characteristics.

In the early stages of investigating shellfish poisoning events, it was not clear whether illness was caused by chemical or microbiological agents ${ }^{4,5}$. Due to this lack of knowledge on the causative agents, early classifications of shellfish poisons were based on the symptoms experienced by humans following consumption of contaminated shellfish. Four categories are distinguished: Paralytic shellfish poisoning (caused by saxitoxins $=$ STX), Neurotoxic shellfish poisoning (caused by brevetoxins = PbTX), Diarrheic shellfish poisoning (caused by okadaic acid $=O A$ ) and Amnesic shellfish poisoning (= ASP, caused by domoic acid = DA). Recently, azaspiracid shellfish poisoning was discovered as a fifth category of shellfish poisoning ${ }^{6,7}$, the symptoms resemble those of diarrheic shellfish poisoning. Ciguatera and tetrodotoxin poisoning are other types of diseases associated with seafood but these illnesses mostly arise from the consumption of fish, and are not further discussed in this context.

The exposure route for shellfish poisoning is through the consumption of shellfish. However, other routes of exposure such as through skin contact and inhalation have been observed for specific algal toxins, these include mainly brevetoxins and possibly palytoxins. The main interest in this paper is on the exposure through consumption of molluscan bivalve shellfish. From a medical point of view, it is now clear that the symptoms of these poisoning syndromes can be easily distinguished from microbiological poisoning by bacteria or viruses through the earlier onset: most bacterial or viral infections require incubation periods of 12 to $24 \mathrm{~h}$ before sickness is experienced by shellfish consumers, while illness from shellfish toxins typically occurs as early as $30 \mathrm{~min}$ after consumption (in case of STX or TTX) or 2 to $4 \mathrm{~h}$ (for most of the other compound groups).

Paralytic shellfish poisoning (PSP) has been reported worldwide ${ }^{8}$. Mild symptoms include altered perception (burning or tingling sensation and numbness of the lips, that can spread to the face and neck), headache, dizziness and nausea. More severe symptoms include incoherent speech, a progression of altered perception to arms and legs, a progressive loss in the coordination of limbs, and general weakness. Respiratory difficulty is a late symptom, as a consequence of muscular paralysis progressing in the whole body, and death may be the outcome of PSP by respiratory paralysis ${ }^{9}$.

Brevetoxins are the causative agents of neurotoxic shellfish poisoning (NSP), that may ensue after both inhaling aerosol containing the toxins and as a consequence of ingestion of contaminated seafood. When poisoning is through the respiratory tract, the exposure usually occurs on or near the waters where a bloom of PbTX producers has developed. NSP has been 
recorded primarily in the south-eastern coast of the United States, the Gulf of Mexico, and New Zealand $^{8,9,10}$. The symptoms due to contaminated shellfish appear after minutes/hours from its ingestion, and are more severe than those found when contaminated aerosol is involved. In the former case, symptoms are both gastro-intestinal (nausea, diarrhea, and abdominal pain) and neurological (circumoral paresthesia and hot/cold temperature reversal). In more severe cases, the muscular system (altered heart contractions, convulsions, and respiratory difficulties) may be affected. Death from NSP has never been reported in humans and, symptoms resolve within a few days after exposure to the toxins ${ }^{8,9}$.

The contamination of seafood by $\mathrm{OA}$ and related compounds is very common in European and Asia-Pacific Countries ${ }^{8}$. The symptoms of DSP appear within $1 \mathrm{hr}$ from ingestion of contaminated seafood, and affect the gastro-intestinal tract with nausea, vomiting, abdominal cramps and diarrhea ${ }^{8}$. The symptoms do not last long and usually disappear within a few days. No death has been recorded due to DSP.

The symptoms due to ingestion of domoic acid contaminated shellfish appear within the first few hours from its ingestion, and in most severe cases, may persist for months ${ }^{11,12,13}$. Initial symptoms affect the gastro-intestinal tract with nausea, vomiting, abdominal cramps and diarrhea. These are followed by headache and other neurological symptoms, that often result in disturbances to memory, an effect that has led to the naming to this shellfish poisoning. In most severe cases, death may ensue. The neurological symptoms of ASP have been shown to evolve in the weeks (months) following poisoning, and anterograde memory disturbances can be accompanied by confusion, disorientation, peripheral nerve damage and changes in memory threshold.

The symptoms of azaspiracid poisoning in humans are very similar to those described for DSP, including nausea, vomiting, abdominal cramps and diarrhea, that disappear within a few days from the ingestion of contaminated shellfish ${ }^{6}$. An overview of molecular mechanisms of action of phycotoxins has been provided in a recent review ${ }^{14}$.

Overall, it is difficult to assess the true occurrence of shellfish poisoning in the human population, as for most diseases. Due to the rapid disappearance of the gastro-intestinal symptoms, many shellfish consumers do not even declare the illness to a medical doctor. However, in some cases, in particular when many people get sick from the consumption of traceable lots of shellfish, the illnesses can be properly diagnosed as shellfish poisoning. It is mostly these cases that are used in the assessment of how much toxin will cause symptoms in shellfish consumers ${ }^{23}, 36$. In US, during the period from 1990 to 1998 , PSP outbreaks were responsible for about $20 \%$ of seafood borne diseases traced to molluscan shellfish ${ }^{15}$. Frequent low incidences of shellfish toxins, many of which are not reported, are sometimes overshadowed by large-scale incidences where several tens or hundreds of people become ill (Table 3).

$A$ recent Codex standard outlines progress at international level on agreement with regards to allowable levels of phycotoxins in shellfish ${ }^{60}$, e.g. the levels for OA- and AZA-group toxins are laid down to be $0.16 \mathrm{mg} / \mathrm{kg}$ shellfish meat.

\section{Characteristics of phycotoxin contamination and shellfish production, and the resulting requirements for detection techniques}

\section{Predictability of the accumulation of phycotoxins in shellfish}

The factors influencing the accumulation of phycotoxins in shellfish are studied intensively. Some toxins are accumulated very regularly by specific shellfish species in some areas, e.g. the occurrence of Pseudo-nitzschia spp. (causative agents of domoic acid, amnesic shellfish poison) can often be predicted through knowledge on the timing of spring and autumn blooms $^{16,17}$, with an inter-annual precision of several weeks. Similarly, the appearance of certain Alexandrium species can be predicted from knowledge on the temperature, irradiance and salinity $^{18}$. In general, however, for many algal species the prediction of contamination levels to be expected remains very challenging due to a number of factors. Such factors typically include physical parameters (weather and climate-related parameters, such as temperature, wind and light conditions, as well as hydrography), chemical parameters (nutrient nature and availability or 
eutrophication, oxygen availability, anthropogenic pollution, ocean acidity) and biological parameters (evolution of algal community structure, occurrence of grazing and parasitic microorganisms). In addition, factors related to shellfish also contribute to the complexity of the phenomenon; these parameters include culture conditions, such as rope-growth of mussels or bottom-growth (ranching). Furthermore, filtration of seawater by bivalves is impacted by their feeding status, species-specific filtration rates and selectivity, as well as micro-organisms affecting shellfish such as pathogenic bacteria and viruses, and several nuisance organisms including algae and cyanobacteria. Additionally, shellfish also show significant differences in metabolism ${ }^{19,56,57}$. Many of these parameters are inter-related and result in very complex and changing scenarios. For instance, duration of contamination may be related to season, and the occurrence of the same alga in summer may lead to shorter contamination episodes than its occurrence in autumn. While many of the factors affecting shellfish can be actively managed, in particular those related to culture techniques and conditions, many factors affecting the occurrence of algae are impossible to control and difficult to predict. As temperature and light conditions affect the growth of algae directly, many models for prediction are based on those parameters. However, the forecasting capability of these models remains limited, mainly due to the poor ability to forecast weather for more than 1 week $^{58}$, which is generally not sufficient warning for the shellfish industry to change harvest patterns or to relocate large quantities of shellfish. Also, prediction models have difficulty in incorporating biological parameters, in particular inter-annual variations of the phytoplankton community structure and occurrence of parasitic organisms of micro-algae or conditions leading to significant cyst formation and hatching. Thus, contamination events have also been encountered at quite surprising times, e.g. Azaspiracids may appear as early as mid July $^{19}$ or as late as mid October ${ }^{6}$. These unprecedented occurrences of algae may also be a function of climate change and may thus be expected more frequently in the near future. Due to these unpredictable occurrences of phycotoxins, it is generally necessary to verify the presence of a number of compound groups before shellfish reach the market. While local monitoring authorities may attempt to counterbalance this need through regular monitoring of the presence of algae, these monitoring systems may also fail due to geographical patchiness of algal occurrence and the rapid onset of blooms and their rapid accumulation in shellfish, which often may be as short as 2-3 days. In addition, official monitoring results are not always communicated in real time to shellfish producers. Therefore, shellfish producers are often faced with the responsibility to monitor their products for a number of toxins groups prior to the decision to take the shellfish out of the water or prior to processing them, and placing on the market. The methods used for such screening must therefore cover a number of toxin groups and must be sensitive enough to detect low levels which may alert shellfish producers to potential problems (see also Table 4).

\section{Economic drivers affecting requirements for detection methods}

The challenges in the production of shellfish are multiple. Production efficiency is related to environmental parameters and local conditions as well as production mode and implementation. In addition, natural factors such as summer mortality, shellfish pathogens and storm conditions may significantly reduce annual production by up to $80 \%$ in some years. Further food safety risks also arise at a high level from microbiological human pathogens, such as viruses (in particular norovirus) and bacteria (in particular vibrios). While official microbiological classification of harvest areas results in a continuous cost of producing safe live bivalve molluscs (in moderately polluted or, in Europe, class B areas), peak occurrences of pathogens may also lead to unpredictable closures reducing the productivity of a given harvest area.

With the exception of oysters and scallops, bivalve molluscs as a raw product are considered low-cost food in most countries; typical prices being less than $1000 € /$ metric ton at production level. This is very much in contrast with many other foods, e.g. crustaceans such as lobster or crab, which may easily yield 5 to 10 times higher income to producers, even though meat yield may be very similar. In view of this low value, end-product testing of shellfish safety becomes a major challenge. In the production of shellfish, the price for a single end-product test may be around $100 €$ (or higher if it is commercially outsourced). As algae occur often in thin layers, and with patchy structures, production lots may be contaminated very inhomogeneously. Depending 
on what would be considered a representative number of tests to conduct per production batch, proper end-product testing could cost as much as $10 \%$ of the total product value.

The globalisation of shellfish trade may result in complex situations whereby toxin groups may need to be detected that would not necessarily be expected in a particular country at a specific time of year. For instance, bivalve molluscs from Ireland in February would not be considered a high risk as there is little toxic algae occurring during this time of year in Ireland. However, if an Irish processing company imports mussels from the Southern hemisphere during this time of year, there could be a risk of such product to contain toxins if there were any failures in the local monitoring programmes.

The commercialisation of shellfish throughout the year (beyond traditional consumption periods) also contributes to a particular need for comprehensive confirmatory testing of shellfish placed on the market. The economic difficulties encountered by many shellfish producers, together with changing habits leading to consumption of shellfish any time of the year, result in a need to produce shellfish almost throughout the seasons. To satisfy these consumption patterns, shellfish producers have to take either more risks to produce live bivalve molluscs close to toxic periods (increased product rejection rates and possibly loss of customer confidence), or to produce shellfish in formats that can be stored for prolonged periods (frozen, canned or pickled shellfish, with increased production cost that can not necessarily be recovered through the increased price). These production modes require particular care, either due to difficulties related to the potential rapid appearance of toxic algae, or through the increased need for verifying that stored product (from different periods of year or from different regions) is still traceable and compliant, i.e. free of a range of toxin groups.

A recent in-depth review of the Irish rope mussel sector ${ }^{20}$ can serve as an example of the economic status of the bivalve mollusc sector. This report indicates that profit margins varied between 1 and $8 \%$ on average (for the years 2003 to 2005), depending on producer and production year. The number one factor influencing productivity and profitability of the rope mussel sector are marine biotoxins. This also means that in years of high biotoxin occurrence, some producers will invariably be in red figures. In addition, the structure of the shellfish industry is still dominated by a large percentage of small and medium sized enterprises. Therefore, if biotoxins occur at high levels during consecutive years, some small producers will risk bankruptcy due to lack of income. Hence, test methods must be cheap, in particular for their use in end-product testing by shellfish industry (Table 4).

\section{Performance of mouse bioassay and mass spectrometric methods for the detection of lipophilic toxins in official control}

As mentioned above, shellfish toxins pose particular problems to public health protection due to a number of differences compared to other contaminants. In particular, the lack of prediction capability of the occurrence of shellfish toxins is a major complicating factor. In combination with the requirement to produce live bivalve molluscs, this results in the need for continued monitoring of shellfish harvesting areas. Since the 1980s, official control in many countries has been carried out using mouse bioassays (MBA) for lipophilic toxins (azaspiracids, okadaic acid group toxins, pectenotoxin and yessotoxin group toxins). More recently, in some countries, e.g. Germany and Sweden, LC-MS based methodology has been used as the primary detection tool; in other countries, e.g. Norway, Ireland and the Netherlands, the bioassays have been complemented by LC-MS in the official monitoring programs.

A previous study has examined the comparability of the EU harmonised mouse bioassay (MBA) for lipophilic toxins with an LC-MS based method at the example of a well-characterised set of blue mussel tissues ${ }^{21}$. This study has shown that the MBA can detect azaspiracids at the current regulatory limit of $160 \mu \mathrm{g} / \mathrm{kg}$. At the same time, the study also clearly demonstrates that the assay can not reliably detect any concentration below this level. Comparison of these data with Aune et al. (2007) ${ }^{22}$ allows for the assumption that dose-response curves of shellfish toxins are similar in the MBA, with the only difference consisting in the $L C_{50}$ of each compound $\left(\mathrm{LC}_{50}\right.$ being the concentration lethal to $50 \%$ of the animals). Thus, it also becomes apparent that the detection capability of the MBA for OA-group toxins is significantly poorer than for azaspiracids. 
In fact, the probability to detect a positive result at the current regulatory limit has been estimated to be less than $50 \%$ for $\mathrm{OA}^{23}$. In practise, this lack of detection capability at the regulatory limit has for instance led to ca. $10 \%$ of samples above $160 \mu \mathrm{g} / \mathrm{kg}$ OA-equivalents not being detected by the MBA in France, over the period from 2003 to $2008^{24}$.

Several examples of shellfish toxin occurrences in the field were examined using data from the Irish and French official monitoring programmes to illustrate the difficulties encountered in protecting the consumer from the risk of shellfish toxins. In either monitoring system, the accumulation of toxins in blue mussels has been followed using the MBA and LC-MS based methods in parallel. The first case (Fig.1) could be described as a classical event, as it involves toxins that have been reported to make shellfish consumers sick at levels incurred during the event (in this case, no sickness occurred as monitoring results were known to regulatory authorities immediately, and closure of the harvest areas prevented any risk to the public). Part c of Fig.1 outlines the results of the MBA, which is the regulatory test in many countries, including Ireland. It is apparent that using the MBA, the toxicity appears without warning, i.e. from the week of $9^{\text {th }}$ to $16^{\text {th }}$ of July 2001. If the chemical monitoring which was ongoing in parallel had not already indicated low levels of toxins of the AZA-group (see part a) of Fig. 1), the area may only have been closed on the $18^{\text {th }}$ of July 2001, i.e. 9 days from the last "non-toxic" sample date (weekly sampling plus $48 \mathrm{~h}$ from the sample taken to the result obtained). This would have resulted in harvesting of the area for probably 3-5 days with high toxicity present in shellfish which may have led to illness if these shellfish had been marketed. The rapid accumulation of shellfish toxins is a phenomenon which has often been underestimated and may lead to severe public health problems as well as to significant economic losses if endproduct testing is carried out efficiently and timely.

In the same graph, it is also apparent that two shellfish toxin groups may co-occur independently; in this case, OA-group toxins and AZA-group toxins. This co-occurrence may be governed by hydrographic and environmental conditions but it is not necessarily reproducible, as shown by comparison of Fig.1 with Fig. 2 (2001/2 versus 2008/9). Due to the possible cooccurrence of several toxin groups, the methods used in official control of harvesting areas must be comprehensive (Table 4). The MBA is capable of detecting both OA and AZA-group toxins, as are many of the in-house validated LC-MS based methods ${ }^{25,26,27}$. If a (hypothetical) AZAspecific ELISA had been the only technique used to detect toxins, the toxicity of the OA-group could have been neglected, and the shellfish growing area could have been reopened prematurely in January 2002 for the 2001 event (Fig.1). Similarly, if only a protein phosphatase assay (specific for OA-group toxins) had been used in official control of the harvesting area in Ireland in 2008, the area would have remained open in the month of June; yet, serious illness would have befallen the consumers of the shellfish due to the presence of AZA-group toxins (Fig. 2). Therefore, shellfish producers and official control authorities need to know all the agents potentially causing hazards in specific areas such that methods appropriate for public health protection can be implemented.

Another aspect of shellfish area management is also illustrated in Figures 1 to 2: the natural detoxification of shellfish in the growing area is significantly slower than the accumulation period. Thus, although the presence of (potentially) toxic algae may only last several days or weeks, the toxicity may persist in shellfish for many months after the algal bloom has disappeared. In this case, toxicity was still above threshold for 6 months after the algal appearance. These prolonged closure periods are potentially a problem for public health protection authorities, as they involve much effort in risk communication; many consumers in shellfish producing countries would be aware of the occurrence of shellfish toxicity during summer months, however, prolonged toxicity into winter months is a less known phenomenon and requires additional efforts in managing the risks. In addition, it has been noted that detoxification rates are higher in the beginning of the detoxification ${ }^{59}$, and the very slow detoxification during later periods causes many problems to shellfish producers. Therefore, competent authorities also frequently face further difficulties in effectively implementing closure of production areas over these long periods. The prolonged retention of toxins also means that it is difficult for importing countries to keep track of the contamination levels in other locations, a complication which results in the need for detection of many toxin groups in imported shellfish.

Apart from the abovementioned economic boundaries in which shellfish producers operate, there are also challenges associated with emerging toxins and the type of testing used in official control. As mentioned above, official control has historically relied upon animal testing to assess 
the toxicity present in shellfish samples. Over the years, the compound groups responsible for causing shellfish poisoning have been identified ${ }^{28}$, yet due to lack of pure compounds toxingroup specific methods have not been implemented as official methods for most toxin groups (apart from DA and STX). The event shown in Fig. 3 exemplifies differences in the interpretation of toxic events, depending on the method used in the official control of harvesting areas. In this area, okadaic acid-group toxins known to cause human poisoning exceed the regulatory limit only during one week during the summer of 2005. Other toxin groups have also been monitored, including pectenotoxins, which occurred at very low levels, and always below regulatory levels. Additionally, all other regulated lipophilic toxins (YTXs and AZAs) and known non-regulated bioactive compounds (gymnodimines and spirolides) were either totally absent or present at levels more than 10-fold lower than the regulatory limits. Yet, the MBA as reference test repeatedly gave positive results for the area over the whole summer period. In fact, the area could not be opened during summer 2005 due to the sporadic occurrence of positive results.

These positive results of the MBA may be related to yet unknown toxins of public health relevance, or they may be due to interference from bioactive compounds which are not relevant to public health. Thus, in a regime which had been based on chemical analysis (by LC-MS), production would have continued after a 3-week closure period (one week toxin levels exceeded regulatory limits and 2 consecutive clear tests are required to re-open an area). The following year showed an even more dramatic picture where MBA results were again sporadically positive between May and September, while all lipophilic toxins known to occur in this area (OA, AZA, PTX, GYM, SPX, YTX) were well below the threshold expected to result in positive results in MBAs (Fig. 4). The situation in Arcachon in 2006 had been further complicated by the fact that anecdotal evidence provided by oyster producers from the area suggested that consumption of these oysters did not result in acute human illness. Additionally, there has also been no epidemiological evidence from official health surveillance bodies suggesting a problem of public health in the area over the period from 2005 to 2009. Further research will be required to establish whether these positive MBA results are indicative of significant risks to the consumers of shellfish.

The above considerations demonstrate that the MBA for lipophilic toxins can not be effectively used to follow quantitatively the uptake of toxins in shellfish and their detoxification. This limitation brings a number of difficulties with it, as it means that the producers are not able to evaluate the official monitoring results to plan ahead their production activities.

Overall, the studies examining the performance of the MBA also suggest that the sensitivity of the assay is not sufficient to detect toxins of the okadaic acid group at the regulatory limit. The increase of toxins in heat treatment similar to commercial processing of shellfish has been previously shown for both the azaspiracid and the okadaic acid group ${ }^{29,30,31}$, and it has been recognised that the prediction of toxin levels in processed product is impossible using the MBA assay $^{32}$. Therefore, the lack in detection capability of the MBA results in serious deficiencies for its use for commercial pre-harvest and end product testing. This limitation also leads to difficulties for the shellfish industry to use results of official control conducted with the MBA.

\section{Screening and confirmatory approaches for end product testing and official control}

In most cases where screening and confirmatory approaches are used in official control to manage contamination of food matrices by chemical substances, the screening method will have less specificity than the confirmatory method. A classical example for screening would be a four-plate test used in the monitoring of antibiotic residues in finfish, which, if positive, should be confirmed by HPLC-FLD analysis following SPE clean-up or by LC-MS-MS analysis. The criteria required for the screening and confirmatory methods to be used in veterinary residue analysis have been defined in EU legislation ${ }^{33}$. On the contrary, the MBA, despite its unspecific character, had been implemented as the reference test for lipophilic marine biotoxins in the EU and was therefore considered to be the confirmatory method ${ }^{34,35}$. Following a number of expert consultations by $\mathrm{FAO} / \mathrm{IOC} / \mathrm{WHO}^{15}$ and $\mathrm{EFSA}^{23,32,36,37,38,39,40}$ under the auspices of Codex 
Alimentarius and the EU Commission for Health and Consumer Protection (DG Sanco), respectively, current discussions at EU level are ongoing to reconsider this position.

The expert consultation by $\mathrm{FAO} / \mathrm{IOC} / \mathrm{WHO}^{15}$ had considered a number of alternative methods for the 8 toxin-groups examined: ELISA (BTX-, DA-, OA-, STX- and YTX-groups), functional assays (receptor-binding assays for the BTX-, DA- and STX-groups; saxiphilin- and neuroblastoma-assay for the STX-group; PP2A for the OA-group), and LC-UV/FLD or - MS for all 8 groups. Overall, LC-UV was recommended for the DA-group, LC-FLD for the STX-group and LC-MS for all other groups as reference method.

Similarly, the summary opinion of EFSA on currently regulated shellfish toxins ${ }^{41}$ concluded that LC-MS has the best potential to replace animal assays for lipophilic toxins, thanks to the advantages of the methods in terms of comprehensiveness and detection capability. In this context, the question may be posed as to whether this recommendation makes sense only for official control purposes or also for commercial pre-harvest monitoring or end-product control by shellfish business operators.

In many current scenarios, where most countries do not communicate official control results rapidly to all stakeholders and where test methods are often not quantitative and not specific (in case of MBA tests), the shellfish business operators have to consider the use of very expensive tests to ensure the safety of their product. These tests are either based on MBA (but this practice is risky, as the test does not have sufficient detection capability) or the tests are based on rapid test kits. In case rapid test kits are used, these should normally comprise a number of different techniques such antibody based assays (enzyme-linked immunosorbent assays42, surface plasmon resonance43,44 or lateral flow immuno-chromatography45) or functional assays 46,47 in order to cover the whole range of toxins that may occur in any given area. As at least 3-4 of the groups in Table 2 have been shown to co-occur (e.g. OA-, AZA- and PTXgroups, Fig.1), it becomes apparent that few of the rapid methods are currently capable of detecting the whole range of toxins required to guarantee compliance with the current regulation. For instance, for AZA, there is only LC-MS methods available25,26,27 as alternative to the MBA. Even for combinations of OA, PTXs and YTXs (as previously reported from Italy and Norway), conscientious shellfish business operators would have to use 2 ELISAs for YTX and PTXs (not currently commercialised for PTXs) and a PP2a assay for OA-group toxins to cover the range of toxins potentially present. Such product control is prohibitively expensive unless the company is organised to conduct all assays at full capacity and for a large number of different shellfish samples. In the ideal scenario, the results of official control are communicated in real-time to all stakeholders (shellfish consumers and shellfish business operators). Such communication can be implemented through publication of test results on web-based information systems, as is already the case for instance in Ireland and Galicia, Spain. If quantitative toxin-specific methods such as LC-MS are implemented in official control, shellfish business operators can use these results to build up historical information as regards to toxin profiles and concentrations in particular production areas. Equally, these results can then be used to focus the shellfish business operators' own controls on the toxin groups shown to be present in any given area at any time. In this way, it may become economical to also use other rapid detection kits (including ELISAs, PP2a and others) for the detection of shellfish toxins in food business operators' own checks, such as controls part of the Hazard Assessment and Critical Control Points (HACCP).

\section{Conclusions and recommendations}

From the above consideration, it appears that the occurrence of shellfish toxins remains difficult to predict for more than 1 week, due to the dependence of currents on weather and complex dynamics of the development of algal blooms. This situation should be improved through the development of in-situ detection tools and improved modelling including some of the biological parameters typically neglected. Notwithstanding those possible improvements, official control requires comprehensive cover of a number of toxin groups to ensure best information to shellfish consumers and producers, and there appears to be a lack of methods with sufficient scope and detection capability. In particular, while the MBA for lipophilic toxins has been shown capable of detecting several compound groups, it has also been shown to lack in detection 
capability, while rapid test kits lack in scope if used individually. The detection capability of rapid test kits and their usefulness through ease of application have been shown; therefore, it is desirable that rapid testing technology be extended to cover a wider range of toxin groups to reduce cost for end-product testing. Additional requirements have been discussed including the freshness of shellfish, the economic pressures in shellfish production and the need for quantitative results to predict the behaviour of shellfish lots in processing. As a consequence, there is a strong need to implement quantitative methods of wide scope and detection capabilities in official monitoring, which, at this point in time can best be ensured through the implementation of multi-toxin LC-MS techniques, an approach under revision at EU Commission level. It is recommended that such an approach would be accompanied by the implementation of rapid, web-based information systems disseminating test results of official control of shellfish and on algal occurrence to enable shellfish business operators to put low-cost, rapid detection tools in place as part of their HACCP plans. Biological methods should also continue to play a role in the screening of shellfish for potentially emerging bioactive compounds. In the author's opinion, a suite of cellular and functional bioassays should be most useful to complement the currently used live animal assays.

\section{Acknowledgements}

I would like to acknowledge the financial contribution of the Irish Department of Agriculture, Fisheries and Food (MAFF) to the national surveillance programme for marine biotoxins, as implemented by the Marine Institute, Ireland. The results of this surveillance programme are available on the web and have been used for figures 1 and 2. I would also like to acknowledge the financial contribution provided by the French Ministry for Food, Agriculture and Fisheries (MAAP), Directorate General for Food (DGAL), programme 206, as well as the contribution provided by the French Ministry for Research, programme 187, to the French national surveillance network for phytoplankton and phycotoxins (REPHY), as implemented by IFREMER. The results of this surveillance programme have been used for figures 3 and 4 .

\section{References}

1. Satake M, MacKenzie L, Yasumoto T (1997) Identification of Protoceratium reticulatum as the biogenetic origin of yessotoxin. Nat. Toxins 5, 164-167.

2. Krock B, Tillmann U, John U, Cembella AD (2009) Characterization of azaspiracids in plankton size-fractions and isolation of an azaspiracid-producing dinoflagellate from the North Sea. Harmful Algae 8, 254-263.

3. Tillmann U, Elbrachter M, Krock B, John U, Cembella A (2009) Azadinium spinosum gen. et sp nov (Dinophyceae) identified as a primary producer of azaspiracid toxins. Eur. J. Phycol. 44, 63-79.

4. Virchow R (1885) Über die Vergiftungen durch Miesmuscheln in Wilhelmshaven. Berliner Klinische Wochenschrift 48, 1-2.

5. Wolff M. (1887) Über das erneute Vorkommen von giftigen Miesmuscheln in Wilhelmshaven. Virchows Arch. 110, 376-380.

6. McMahon T, Silke J (1996) Winter toxicity of unknown aetiology in mussels. Harmful Algal News 14, 2.

7. Satake M, Ofuji K, Naoki H, James KJ, Furey A, McMahon T, Silke J, Yasumoto T (1998) Azaspiracid, a new marine toxin having unique spiro ring assemblies, isolated from Irish mussels, Mytilus edulis. J. Amer. Chem. Soc. 120, 9967-9968.

8. (2004) FAO Food and Nutrition Paper 80, Food and Agriculture Organisation of the United Nations, Rome, 2004. van Egmond H.P., van Appeldoorn M.E. and Speijers G.J.A.

9. Gessner BD, McLaughlin JB (2008) Epidemiologic impact of toxic episodes: neurotoxic toxins. In: LM Botana (ed.): Seafood and Freshwater Toxins, Pharmacology, Physiology and Detection, Taylor \& Francis Ltd, Boca Raton, 77-103. 
10. Ishida H, Muramatsu M, Kosuge T, Tsuji K. (1996) Study on neurotoxic shellfish poisoning involving New Zealand shellfish Crassostrea gigas. In: T. Yasumoto, Y. Oshima and Y. Fukuyo (eds.): Harmful and Toxic Algal Blooms, Intergovernmental Oceanographic Commission of UNESCO, 491-494.

11. Perl TM, Bedard L, Kosatsky T, Hockin JC, Todd EC, Remis RS (1990) An outbreak of toxic encephalopathy caused by eating mussels contaminated with domoic acid. N. Engl. J. Med. 322, 1775-1780.

12. Quilliam MA, Wright JLC (1989) The amnesic shellfish poisoning mystery. Anal. Chem. 61, 1053-1060.

13. Teitelbaum JS, Zatorre RJ, Carpenter S, Gendron D, Evans AC, Gjedde A, Cashman NR (1990) Neurologic sequelae of domoic acid intoxication due to the ingestion of contaminated mussels. N. Engl. J. Med. 322, 1781-1787.

14. Rossini GP, Hess P. (2010) Phycotoxins: chemistry, mechanism of action and shellfish poisoning. Chapter 2.3 in "Clinical Toxicology", p. 65 - 122; Vol. 2. Andreas Luch (ed.) "Experientia Supplementa" (EXS) book series, Birkhäuser Publishing, Basel.

15. FAO (2005) Report of the Joint FAO/IOC/WHO ad hoc Expert Consultation on Biotoxins in Bivalve Molluscs, Oslo, Norway, Sept. 26-30, 2004 (advance pre-publication copy: http://www.fao.org/es/ESN/food/risk_biotoxin_en.stm);

ftp://ftp.fao.org/es/esn/food/biotoxin report en.pdf

16. Bates SS, Garrison DL, Horner RA. (1998) Bloom dynamics and physiology of domoic-acidproducing Pseudo-nitzschia species. In Anderson, D. M., Cembella, A. D. \& Hallegraeff, G. M. [Eds.] Physiological Ecology of Harmful Algal Blooms. Springer- Verlag, Heidelberg, pp. 267-92. 17. Turrell E, Bresnan E, Collins C, Brown L, Graham J, Grieve M. (2008) Detection of Pseudonitzschia (Bacillariophyceae) species and amnesic shellfish toxins in Scottish coastal waters using oligonucleotide probes and the Jellet Rapid Test. Harmful Algae 7, 443-458.

18. Touzet N, Franco JM, Raine R (2008) PSP toxin analysis and discrimination of the naturally co-occurring Alexandrium tamarense and A. minutum (Dinophyceae) in Cork Harbour, Ireland. Aquat. Microb. Ecol. 51, 285-299.

19. Hess P, McMahon T, Slattery D, Swords D, Dowling G, McCarron M, Clarke D, Gibbons W, Silke J, O'Cinneide M. (2003) Use of LC-MS testing to identify lipophilic toxins, to establish local trends and interspecies differences and to test the comparability of LC-MS testing with the mouse bioassay: an example from the Irish biotoxin monitoring programme 2001. in : Molluscan Shellfish Safety; editors: A. Villalba, B. Reguera, J.L. Romalde, R. Beiras; publishers: Xunta de Galicia and Intergovernmental Oceanographic Commission of UNESCO, Santiago de Compostela, Spain. 2003 ISBN: 84-453-3638-X.

20. BIM (2006) Review of the Irish Rope Mussel Industry, a report jointly commissioned by Board Iascaigh Mhara (BIM) and Entreprise Ireland. PricewaterhouseCoopers, March, 2006.

21. Hess P, Butter T, Petersen A, Silke J, McMahon T. (2009) Performance of the EU harmonised mouse bioassay for lipophilic toxins for the detection of azaspiracids in naturally contaminated mussel (Mytilus edulis) hepatopancreas tissue homogenates characterised by liquid chromatography coupled to tandem mass spectrometry. Toxicon 53, 713-722.

22. Aune T, Larsen S, Aasen J, Rehmann N, Satake M, Hess P. (2007) Relative toxicity of dinophysistoxin-2 (DTX-2) compared with okadaic acid, based on acute intraperitoneal toxicity in mice. Toxicon 49, 1-7.

23. EFSA (European Food Safety Authority) (2008a) Marine biotoxins in shellfish - Okadaic Acid and analogues, Scientific Opinion of the Panel on Contaminants in the Food chain, adopted on 27 November 2007, EFSA Journal 589, 1-62.

24. Belin C, Soudant D, Amzil Z. (2009) Surveillance des toxines lipophiles dans les coquillages. Analyses statistique et comparaison des résultats obtenus par deux méthodes d'analyse : les bio-essais sur souris et les analyses chimiques par CL-SM/SM. Rapport exécuté dans le cadre de la Convention Etudes DGAL / Ifremer, correspondant à la Subvention pour charges de service public, Programme 206, 94 pp Octobre 2009.

25. Fux E, McMillan D, Bire R, Hess P. (2007) Development of an Ultra Performance Liquid Chromatography - Mass Spectrometry method for the detection of lipophilic marine toxins. J. Chromatogr. A 1157, 273-280.

26. Gerssen A, McElhinney MA, Mulder PPJ, Bire R, Hess P, de Boer J. (2009) Solid phase extraction for removal of matrix effects in lipophilic marine toxin analysis by liquid chromatography-tandem mass spectrometry. Anal. Bioanal. Chem. 394, 1213-1226. 
27. These A, Scholz J, Preiss-Wiegert A. (2009) Sensitive method for the determination of lipophilic marine biotoxins in extracts of mussels and processed shellfish by high performance liquid chromatography-tandem mass spectrometry based on enrichment by solid-phase extraction. J. Chromatogr. A 1216 (21), 4529-4538.

28. Hess P. (2008) What's new in toxins? Pp 360-370, in "Proceedings of the 12th International Conference on Harmful Algae". (Eds. : Moestrup, Ø., G. Doucette, H. Enevoldsen, A. Godhe, G. Hallegraeff, B. Luckas, N. Lundholm, J. Lewis, K. Rengefors, K. Sellner, K. Steidinger, P. Tester, A. Zingone). International Society for the Study of Harmful Algae and Intergovernmental Oceanographic Commission of UNESCO, 2008 Copenhagen. pp 397.

29. Hess P, Nguyen L, Aasen J, Keogh M, Kilcoyne J, McCarron P, Aune T. (2005) Tissue distribution, effects of cooking and parameters affecting the extraction of azaspiracids from mussels, Mytilus edulis, prior to analysis by liquid chromatography coupled to mass spectrometry. Toxicon 46, 62-71.

30. McCarron P, Kilcoyne J, Hess P. (2008) Effects of cooking and heat treatment on concentration and tissue distribution of okadaic acid and dinophysistoxin-2 in mussels (Mytilus edulis). Toxicon 51, 1081-1089.

31. McCarron P, Kilcoyne J, Miles CO, Hess P. (2009) Formation of Azaspiracids-3, -4, -6, and 9 via decarboxylation of carboxyazaspiracid metabolites from shellfish. J. Agric. Food Chem. 57, 160-169.

32. EFSA (European Food Safety Authority) (2009b) Influence of processing on the levels of lipophilic marine biotoxins in bivalve molluscs, Statement of the Panel on Contaminants in the Food Chain, Adopted on 25 March 2009, EFSA Journal 1016, 1-10.

33. EU (2002) Commission Decision of 12 August 2002, implementing Council Directive 96/23/EC concerning the performance of analytical methods and the interpretation of results. Official Journal EC, L221/8; 17/08/2002.

34. Regulation (EC) No 853/2004 of the European Parliament and of the Council and for the organisation of official controls under Regulation (EC) No 854/2004 Official Journal L 226, 25/06/2004 P. $0022-0082$.

35. Commission Regulation (EC) No 2074/2005 of 5 December 2005 laying down implementing measures for certain products under Regulation (EC) No 853/2004 of the European Parliament and of the Council and for the organisation of official controls under Regulation (EC) No 854/2004 of the European Parliament and of the Council and Regulation (EC) No 882/2004 of the European Parliament and of the Council, derogating from Regulation (EC) No 852/2004 of the European Parliament and of the Council and amending Regulations (EC) No 853/2004 and (EC) No 854/2004. Official Journal L338, 22/12/2005 P. 0027 - 0059.

36. EFSA (European Food Safety Authority) (2008b) Marine biotoxins in shellfish - Azaspiracid group, Scientific Opinion of the Panel on Contaminants in the Food chain, adopted on 9 June 2008, EFSA Journal 723, 1-52.

37. EFSA (European Food Safety Authority) (2009a) Marine biotoxins in shellfish - Yessotoxin group, Scientific Opinion of the Panel on Contaminants in the Food chain, adopted on the 2 December 2008, EFSA Journal 907, 1-62.

38. EFSA (European Food Safety Authority) (2009c) Marine biotoxins in shellfish - Saxitoxin group; Scientific Opinion of the Panel on Contaminants in the Food Chain, Adopted on 25 March 2009, EFSA Journal 1019, 1-76.

39. EFSA (European Food Safety Authority) (2009d) Marine biotoxins in shellfish - Pectenotoxin group, Scientific Opinion of the Panel on Contaminants in the Food chain; adopted on 27 May 2009, EFSA Journal 1109, 1-47.

40. EFSA (European Food Safety Authority) (2009e) Marine biotoxins in shellfish - Domoic acid group, Scientific Opinion of the Panel on Contaminants in the Food chain; adopted on 2 July 2009, EFSA Journal 1181, 1-61.

41. EFSA (European Food Safety Authority) (2009f) Marine biotoxins in shellfish - Summary Opinion, Scientific Opinion of the Panel on Contaminants in the Food chain; adopted on 13 August 2009, EFSA Journal 1306, 1 - 23.

42. Kleivdal H, Kristiansen SI, Nilsen MV, Briggs L. (2007) Single-laboratory validation of the biosense direct competitive enzyme-linked immunosorbent assay (ELISA) for determination of domoic acid toxins in shellfish. J. AOAC Int. 90, 1000-1010. 
43. Fonfria ES, Vilarino N, Campbell K, Elliott C, Haughey SA, Ben-Gigirey B, Vieites JM, Kawatsu K, Botana L.M. (2007) Paralytic shellfish poisoning detection by surface plasmon resonance-based Biosensors in shellfish matrixes. Anal. Chem. 79, 6303-6311.

44. Stewart L, Hess P, Connolly L, Elliott C. (2009) Development and single laboratory validation of a pseudo-functional biosensor immunoassay for the detection of the okadaic acid group of toxins. Anal. Chem. In press DOI to be confirmed.

45. Jellett JF, Doucette LI, Belland ER. (1998) The MIST (TM) shipable cell bioassay kits for PSP: an alternative to the mouse bioassay. J. Shellfish Res. 17, 1653-1655.

46. Rossini GP. (2005) Functional assays in marine biotoxin detection. Toxicology 207, 451-462.

47. Vale C, Botana LM. (2008) Marine toxins and the cytoskeleton. FEBS J. 275, 6059.

48. Yasumoto T, Oshima Y, Yamaguchi M (1978) Occurrence of a new type of shellfish poisoning in the Tohoku district. Bull. Jpn. Soc. Sci. Fish. 44: 1249-1255.

49. Underdal B, Yndestad M, Aune T. (1985) DSP intoxication in Norway and Sweden, Autumn 1984- Spring 1984. Anderson, D. M., White, A. W., and Baden, D. G. Toxic Dinoflagellates, 489494. Amsterdam, Elsevier.

50. Rodrigue DC, Etzel RA, Hall S, de Porras E, Velasquez OH, Tauxe RV, Kilbourne EM and Blake PA. (1990) Lethal paralytic shellfish poisoning in Guatemala. Am. J. Trop. Med. Hyg. 42, 267-271.

51. Morris P., Campbell D.S., Taylor T.J., Freeman J.I. (1991) Clinical and epidemiological features of neurotoxic shellfish poisoning in North Carolina. Am. J. Public Health 81, 471-473.

52. McMahon T. and Silke J. 1998. Re-occurrence of winter toxicity in Irish mussels. Harmful Algae News 17, 12.

53. De Schrijver K, Maes I, De Man L, Michelet J. (2002) An outbreak of diarrhoeic shellfish poisoning in Antwerp, Belgium. Eurosurveillance 7, 139-141.

54. Aune, T., Torgersen, T., Aasen, J., Castberg, T., Naustvoll, L.-J. and Woll, A. (2006) Risk assessment of DSP toxins in brown crabs (Cancer pagurus). In: Molluscan Shellfish Safety. Proceedings of the 5th International Conference on Molluscan Shellfish Safety, Galway, Ireland, June 14th-18th, 2004 ( Eds.: K. Henshilwood, B. Deegan, T. McMahon, C. Cusack, S. Keaveney, J. Silke, M. O'Cinneide, D. Lyons and P. Hess), pp. 464-468.

55. UK COT (The Committee on Toxicity of Chemicals in Food, Consumer Products and the Environment), 2006. Statement on risk assessment of marine biotoxins of the okadaic acid, pectenotoxin, azaspiracid and yessotoxin groups in support of human health. Available at URL:

http://www.food.gov.uk/multimedia/pdfs/cotstatementlipophilic200616.pdf , accessed $14 / 11 / 2009$.

56. Miles, C.O., Wilkins, A.L., Munday, R., Dines, M.H., Hawkes, A.D., Briggs, L.R., Sandvik, M., Jensen, D.J., Cooney, J.M., Holland, P.T., Quilliam, M.A., MacKenzie, A.L., Beuzenberg, V., Towers, N.R., 2004. Isolation of pectenotoxin-2 from Dinophysis acuta and its conversion to pectenotoxin-2 seco acid, and preliminary assessment of their acute toxicities. Toxicon 43, 1-9.

57. Yasumoto T, Murata M, Lee JS and Torigoe K, 1989. Polyether toxins produced by dinoflagellates. In: Mycotoxins and Phycotoxins '88. Elsevier, Natori S, Hashimoto $\mathrm{K}$ and Ueno Y (ed), Amsterdam, pp. 375-382.

58. Francks P.J.S. 1995 Sampling techniques and strategies for coastal phytoplankton blooms, p. 39 in "Manual on Harmful Marine Microalgae" (editors: G.M. Hallegraeff, D.M. Anderson, A.D. Cembella) IOC Manual and Guides No. 33, UNESCO 1995.

59. Morono, A., Fernandez, M.L., Franco J.M.., Martinez A.., Reyero M.I., Miguez A., Cacho E., Blanco, J., 1998. PS and DSP detoxification kinetics in mussels Mytilus galloprovincialis : effect of environmental parameters and body weight. Harmful Algae. B. Reguera, J. Blanco, M.L. Fernandez and T. Wyatt (Eds.) Xunta de Galicia and Intergovernmental Oceanographic Commission of UNESCO.

60. Codex Standard 292-2008: Standard for live and raw bivalve molluscs.

http://www.codexalimentarius.net/web/index_en.jsp\#

/download/standards/11109/CXS 292e.pdf, website accessed last on 24/12/2009 
Table 1. Characteristics of marine biotoxins, arranged by increasing molecular weight. Chemical class and formula, molecular weights, UV-absorption maxima, acidity constants and lipophilicity. Note, for the smaller toxins (DA, STX) the acidic or basic character outweighs their few lipophilic functions, resulting in overall hydrophilic compounds. The largest molecules have significant polar functions (2 sulphate groups for YTX, multiple OH-groups for PITX and MTX, 2 amide and a primary amine function for PITX, and 2 sulphate groups for MTX) giving them an amphiphilic character despite their long carbon chains (lipophilic part).

\begin{tabular}{|c|c|c|c|c|c|c|}
\hline TOXIN & $\begin{array}{l}\text { CHEMICAL } \\
\text { CLASS }\end{array}$ & FORMULA & $\begin{array}{l}\text { MOLAR } \\
\text { WEIGHT }\end{array}$ & $\begin{array}{l}\text { UV } \\
\text { [NM] }\end{array}$ & $\mathrm{PKA}_{1,2,3,4}$ & $\begin{array}{l}\text { LIPO- } \\
\text { PHILICITY }\end{array}$ \\
\hline SAXITOXIN & $\begin{array}{l}\text { TETRAHYDRO- } \\
\text { PURINE ALKALOID }\end{array}$ & $\mathrm{C}_{10} \mathrm{H}_{17} \mathrm{~N}_{7} \mathrm{O}_{4}$ & 299 & $\mathrm{~N} / \mathrm{A}$ & $8.1,11.5$ & HYDROPHILIC \\
\hline DOMOIC ACID & $\begin{array}{lr}\text { CYCLIC AMINO ACID, } \\
3 & \text { CARBOXY } \\
\text { GROUPS } & \end{array}$ & $\mathrm{C}_{15} \mathrm{H}_{21} \mathrm{NO}_{6}$ & 311 & 242 & $\begin{array}{l}2.1, \quad 3.7 \\
5.0,9.8\end{array}$ & HYDROPHILIC \\
\hline GYMNODIMINE & $\begin{array}{l}\text { CYCLIC IMINE, } \\
\text { MACROCYCLE }\end{array}$ & $\mathrm{C}_{32} \mathrm{H}_{45} \mathrm{NO}_{4}$ & 507 & N/A & N/REP & LIPOPHILIC \\
\hline 13DM-SPIROLIDE C & $\begin{array}{l}\text { CYCLIC IMINE, } \\
\text { MACROCYCLE }\end{array}$ & $\mathrm{C}_{41} \mathrm{H}_{61} \mathrm{NO}_{7}$ & 691 & N/A & N/REP & LIPOPHILIC \\
\hline GAMBIEROL & $\begin{array}{l}\text { LADDERSHAPED } \\
\text { POLYETHER }\end{array}$ & $\mathrm{C}_{43} \mathrm{H}_{64} \mathrm{O}_{11}$ & 757 & N/REP & $\mathrm{N} / \mathrm{A}$ & LIPOPHILIC \\
\hline OKADAIC ACID & $\begin{array}{l}\text { POLYETHER, SPIRO- } \\
\text { KETO ASSEMBLY }\end{array}$ & $\mathrm{C}_{44} \mathrm{H}_{68} \mathrm{O}_{13}$ & 804 & N/A & $4.9^{\S}$ & LIPOPHILIC \\
\hline AZASPIRACID & $\begin{array}{l}\text { POLYETHER, } \\
\text { SECOND AMINE, 3- } \\
\text { SPIRO-RING }\end{array}$ & $\mathrm{C}_{47} \mathrm{H}_{71} \mathrm{NO}_{12}$ & 841 & N/A & $5.8^{\S}$ & LIPOPHILIC \\
\hline PECTENOTOXIN-2 & $\begin{array}{l}\text { POLYETHER, ESTER } \\
\text { MACROCYCLE }\end{array}$ & $\mathrm{C}_{47} \mathrm{H}_{70} \mathrm{O}_{14}$ & 858 & 235 & $N / A^{\S}$ & LIPOPHILIC \\
\hline BREVETOXIN-B & $\begin{array}{l}\text { LADDERSHAPED } \\
\text { POLYETHER }\end{array}$ & $\mathrm{C}_{50} \mathrm{H}_{70} \mathrm{O}_{14}$ & 894 & 208 & $\mathrm{~N} / \mathrm{A}$ & LIPOPHILIC \\
\hline PROROCENTROLIDE & $\begin{array}{l}\text { CYCLIC IMINE, LAC- } \\
\text { TONE MACROCYCLE }\end{array}$ & $\mathrm{C}_{56} \mathrm{H}_{85} \mathrm{NO}_{13}$ & 979 & N/REP & N/REP & LIPOPHILIC \\
\hline P-CIGUATOXIN-4B & $\begin{array}{l}\text { LADDERSHAPED } \\
\text { POLYETHER }\end{array}$ & $\mathrm{C}_{60} \mathrm{H}_{85} \mathrm{O}_{16}$ & 1061 & 223 & $N / A$ & LIPOPHILIC \\
\hline YESSOTOXIN & $\begin{array}{l}\text { LADDERSHAPED } \\
\text { POLYETHER }\end{array}$ & $\mathrm{C}_{55} \mathrm{H}_{82} \mathrm{O}_{21} \mathrm{~S}_{2}$ & 1140 & 230 & $\begin{array}{l}\text { N/REP, } \\
6.9^{\S}\end{array}$ & AMPHIPHILIC \\
\hline PALYTOXIN* & $\begin{array}{l}\text { POLYOL, } 2 \text { AMIDE \& } \\
\text { A PRIMARY AMINE }\end{array}$ & $\mathrm{C}_{129} \mathrm{H}_{223} \mathrm{~N}_{3} \mathrm{O}_{54}$ & 2678 & $\begin{array}{l}263 \\
233\end{array}$ & N/REP & AMPHIPHILIC \\
\hline MAITOTOXIN & $\begin{array}{lc}\text { POLYOL, } & \text { FOUR } \\
\text { FUSED } & \text { RING } \\
\text { SYSTEMS } & \\
\end{array}$ & $\mathrm{C}_{164} \mathrm{H}_{256} \mathrm{O}_{68} \mathrm{~S}_{2} \mathrm{NA}_{2}$ & 3422 & 230 & N/REP & AMPHIPHILIC \\
\hline
\end{tabular}

* Palytoxin from Palythoa toxica; N/a = not applicable; N/rep = not reported

§Fux and Hess (unpublished observations) determined chromatographically (for YTX the pKa 1 was too low to be determined chromatographically, $\mathrm{pKa}_{2}$ is given) 
Table 2. Toxin groups and their biogenetic, micro-algal origins*. Apart from domoic acid which is produced by the diatom Psezudo-nitzschia spp., other phycotoxins are produced by dinoflagellates (STX is also produced by certain cyanobacteria*).

\begin{tabular}{|c|c|c|}
\hline TOXIN-GROUP & ABBREVIATION & ALGAE ASSOCIATED \\
\hline AZASPIRACID & $A Z A$ & AZADINIUM SPINOSUM \\
\hline BREVETOXIN-B & BTX & KARENIA BREVIS \\
\hline DOMOIC ACID & DA & PSEUDO-NITZSCHIA SPP. ${ }^{\S}$ \\
\hline GYMNODIMINE & GYM & KARENIA SELLIFORMIS \\
\hline OKADAIC ACID & OA & DINOPHYSIS SPP. ${ }^{\S}$, PROROCENTRUM SPP. ${ }^{\S}$ \\
\hline PALYTOXIN & PLTX & OSTREOPSIS SPP. ${ }^{\S}$ \\
\hline PECTENOTOXIN-2 & PTX & DINOPHYSIS SPP. ${ }^{\S}$ \\
\hline PROROCENTROLIDE & PCL & PROROCENTURM SPP. ${ }^{\S}$ \\
\hline SAXITOXIN & STX & $\begin{array}{lllll}\begin{array}{l}\text { ALEXANDRIUM } \\
\text { BAHAMENSE }\end{array} & \text { SPP. } & \text { \& }, & \text { G. } & \text { CATENATUM, } \\
\end{array}$ \\
\hline 13DM-SPIROLIDE C & SPX & ALEXANDRIUM OSTENFELDII \\
\hline YESSOTOXIN & YTX & P. RETICULATUM, L. POLYEDRUM, G. SPINIFERA \\
\hline
\end{tabular}

Table 3. Examples of shellfish poisoning incidents. Note that no new toxin groups have been reported since the discovery of azaspiracids in $1995^{28}$. Large-scale poisoning events for okadaic acid group toxins have still occurred during the last decade despite the toxic algae and toxins involved being known for over 20 years.

\begin{tabular}{|c|c|c|c|c|}
\hline POISONING & $\begin{array}{l}\text { NO. OF } \\
\text { CASES }\end{array}$ & $\begin{array}{l}\text { SHELLFISH } \\
\text { SPECIES }\end{array}$ & $\begin{array}{l}\text { LOCATION } \\
\text { OF ILLNESS }\end{array}$ & REFERENCE \\
\hline DSP & 164 & MUSSELS AND SCALLOPS & JAPAN & 48 \\
\hline DSP & $>300$ & BLUE MUSSELS (M. EDULIS) & NORWAY, SWEDEN & 49 \\
\hline ASP & 107 & BLUE MUSSELS (M. EDULIS) & CANADA & 11 \\
\hline PSP & 187 & CLAMS (A. KINDERMANII) & GUATEMALA & 50 \\
\hline NSP & 48 & EASTERN OYSTER (C. VIRGINICA) & UNITED STATES & 51 \\
\hline AZP & 24 & BLUE MUSSELS (M. EDULIS) & IRELAND & 52 \\
\hline DSP & $>\mathbf{3 0 0}$ & BLUE MUSSELS (M. EDULIS) & BELGIUM & 53 \\
\hline DSP & 200 & BROWN CRAB (C. PAGURUS) & NORWAY & 54 \\
\hline DSP & 159 & BLUE MUSSELS (M. EDULIS) & UNITED KINGDOM & 55 \\
\hline
\end{tabular}


Table 4. Characteristics of phycotoxins and shellfish as a commodity, and resulting requirements for detection methods, as a function of the method type (screening or confirmatory method).

\begin{tabular}{|c|c|c|}
\hline $\begin{array}{l}\text { Characteristic } \\
\text { parameter }\end{array}$ & Method type & 7. Resulting requirement \\
\hline \multirow[t]{4}{*}{ Natural products } & Screening & $\begin{array}{l}\text { Coverage of each compound in the group of toxins, } \\
\text { adequate LOD, low rate of false positives }\end{array}$ \\
\hline & \multirow[t]{3}{*}{ Confirmation } & Coverage of each compound in the group of toxins \\
\hline & & $\begin{array}{l}\text { High specificity, low rates of false positive \& negative } \\
\text { results }\end{array}$ \\
\hline & & $\begin{array}{l}\text { Evaluation of toxic equivalent compared to legal limit } \\
\text { (trueness) }\end{array}$ \\
\hline \multirow{2}{*}{$\begin{array}{l}\text { Co-occurrence of } \\
\text { toxin groups, } \\
\text { trade } \\
\text { globalisation, } \\
\text { year-round } \\
\text { production }\end{array}$} & Screening & $\begin{array}{l}\text { Ability to detect several different compound groups in } \\
\text { parallel }\end{array}$ \\
\hline & Confirmation & $\begin{array}{l}\text { Ability to detect several different compound groups in cost- } \\
\text { effective manner and in reasonable timescale }\end{array}$ \\
\hline \multirow[t]{2}{*}{ Shellfish matrix } & Screening & Matrix effects insignificant compared to LOD \& legal limit \\
\hline & Confirmation & $\begin{array}{l}\text { Matrix effects must be accounted for quantitatively } \\
\text { (trueness) }\end{array}$ \\
\hline \multirow{2}{*}{$\begin{array}{l}\text { Heterogeneous } \\
\text { distribution \& } \\
\text { rapid appearance }\end{array}$} & Screening & Representative sub-sampling \& low cost of analysis \\
\hline & Confirmation & Representative sub-sampling, time \& spatial trend analysis \\
\hline \multirow[t]{2}{*}{$\begin{array}{l}\text { Freshness of } \\
\text { shellfish }\end{array}$} & Screening & $\begin{array}{l}\text { Rapid sample turnaround, even for several compound } \\
\text { groups }\end{array}$ \\
\hline & Confirmation & $\begin{array}{l}\text { Rapid sample turnaround, unless screening is used in } \\
\text { parallel }\end{array}$ \\
\hline \multirow[t]{2}{*}{ Low-cost food } & Screening & Low cost of analysis \\
\hline & Confirmation & Reasonable cost of analysis \\
\hline
\end{tabular}



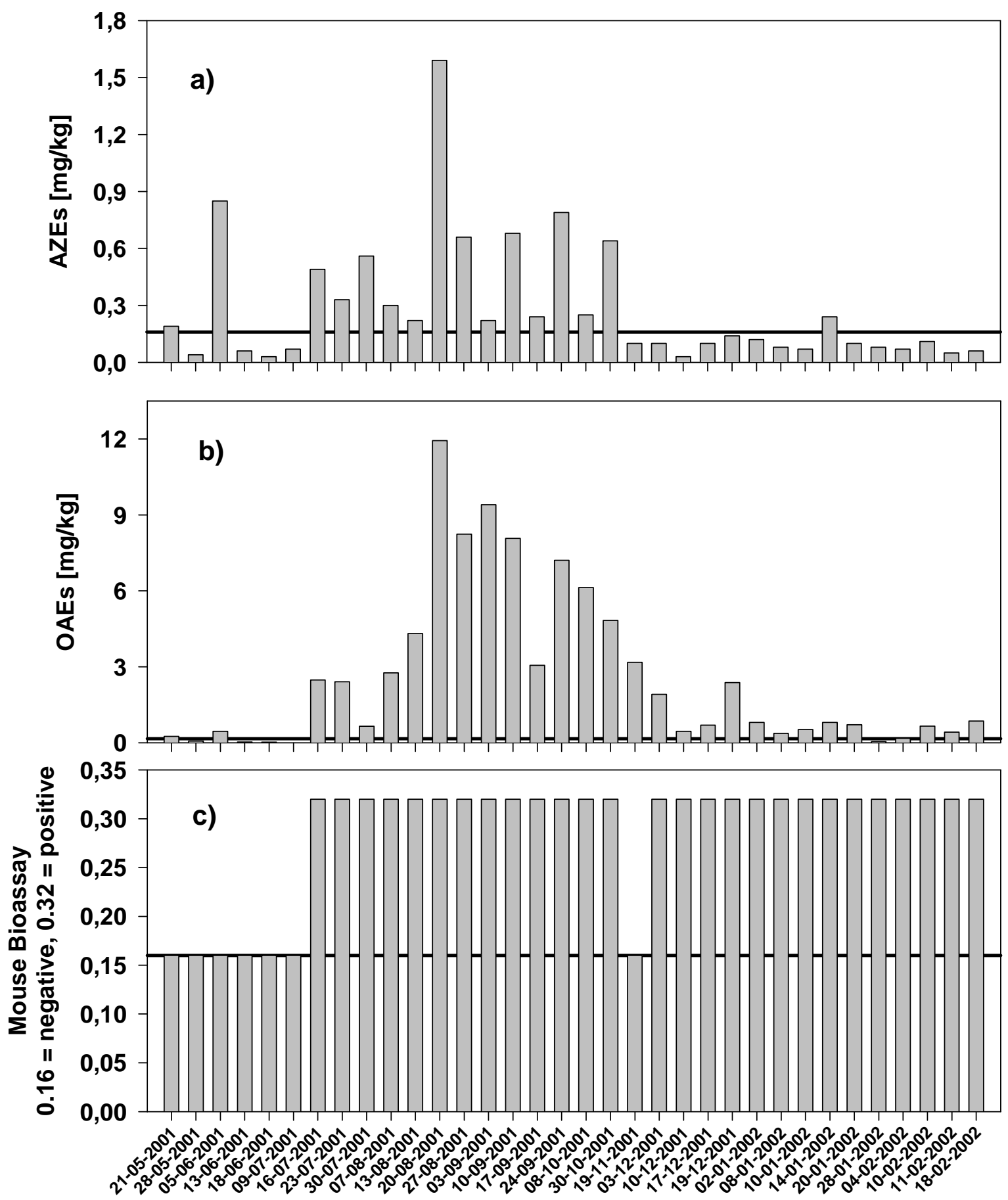

Figure 1

Figure 1. Temporal trends of azaspiracid group toxins, okadaic acid group toxins and mouse bioassay results in mussels (M. edulis) from Castletownbere, southwest Ireland from May 2001 to February 2002; a) azaspiracid-1 equivalents (AZEs) and b) okadaic acid equivalents (OAEs), both determined by LC-MS and measured and expressed in whole shellfish flesh, c) mouse bioassay (MBA) results for the same samples measured in hepatopancreas. The thick black line in each of the three graphs represents the regulatory limit in the EU at the time, i.e. $0.16 \mathrm{mg} / \mathrm{kg}$ for both OA- and AZA-group toxins. Arbitrarily, and for visualisation purposes only, MBA 
negative results are represented as $0.16 \mathrm{mg} / \mathrm{kg}$ values whereas MBA positives are represented as $0.32 \mathrm{mg} / \mathrm{kg}$. (Figure adapted from Hess et al., 2003)
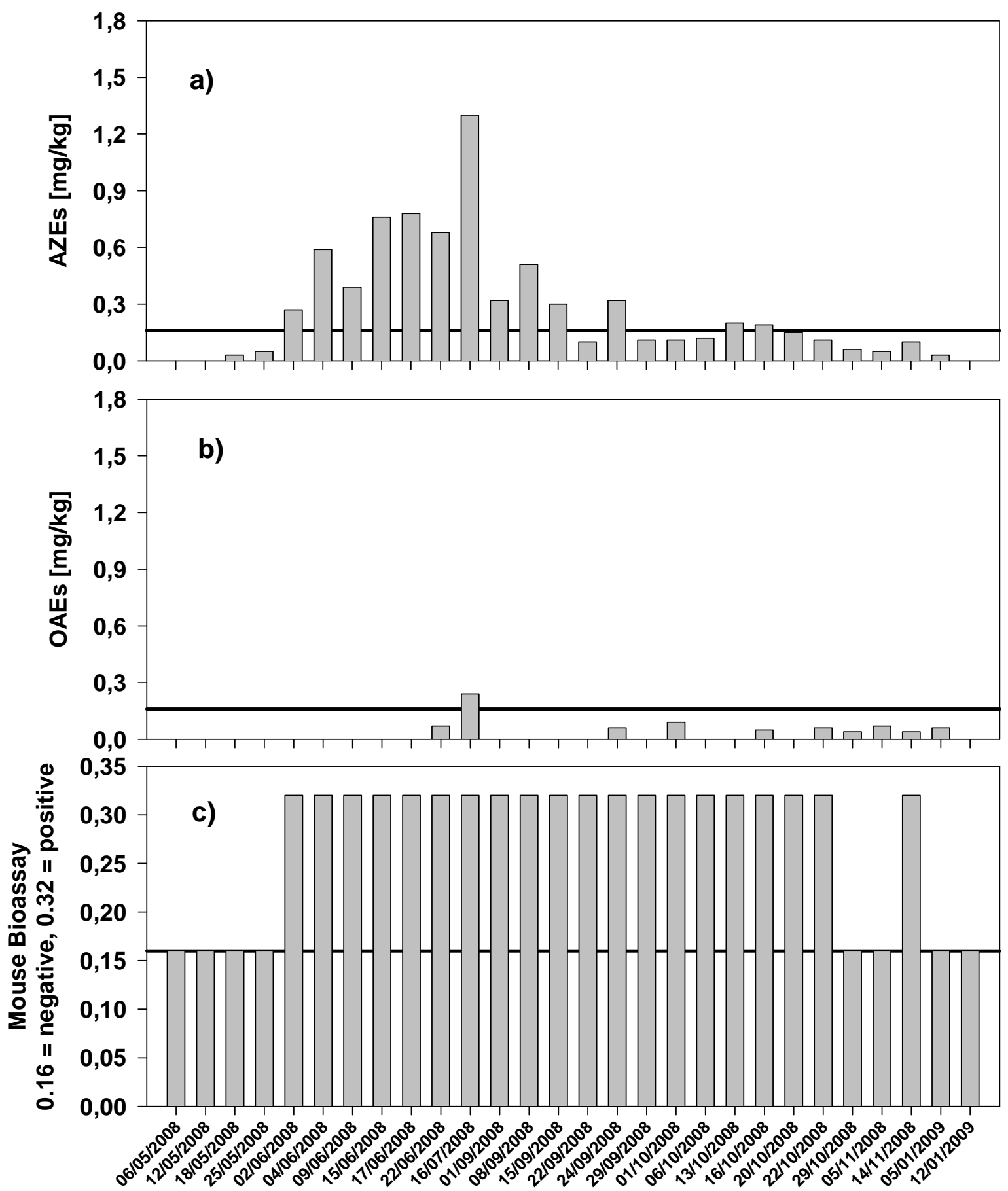

Figure 2

Figure 2. Temporal trends of azaspiracid group toxins, okadaic acid group toxins and mouse bioassay results in mussels (M. edulis) from Castletownbere, southwest Ireland from May 2008 to January 2009; a) azaspiracid-1 equivalents (AZEs) and b) okadaic acid equivalents (OAEs), both determined by LC-MS and measured and expressed in whole shellfish flesh, c) mouse bioassay (MBA) results for the same samples measured in hepatopancreas. The thick black line in each of the three graphs represents the regulatory limit in the $E U$ at the time, i.e. $0.16 \mathrm{mg} / \mathrm{kg}$ for both OA- and AZA-group toxins. Arbitrarily, and for visualisation purposes only, MBA negative results are represented as $0.16 \mathrm{mg} / \mathrm{kg}$ values whereas MBA positives are represented 
as $0.32 \mathrm{mg} / \mathrm{kg}$ (Figure created from data available online from the Marine Institute, at http://www.marine.ie, accessed on 29/07/2009).
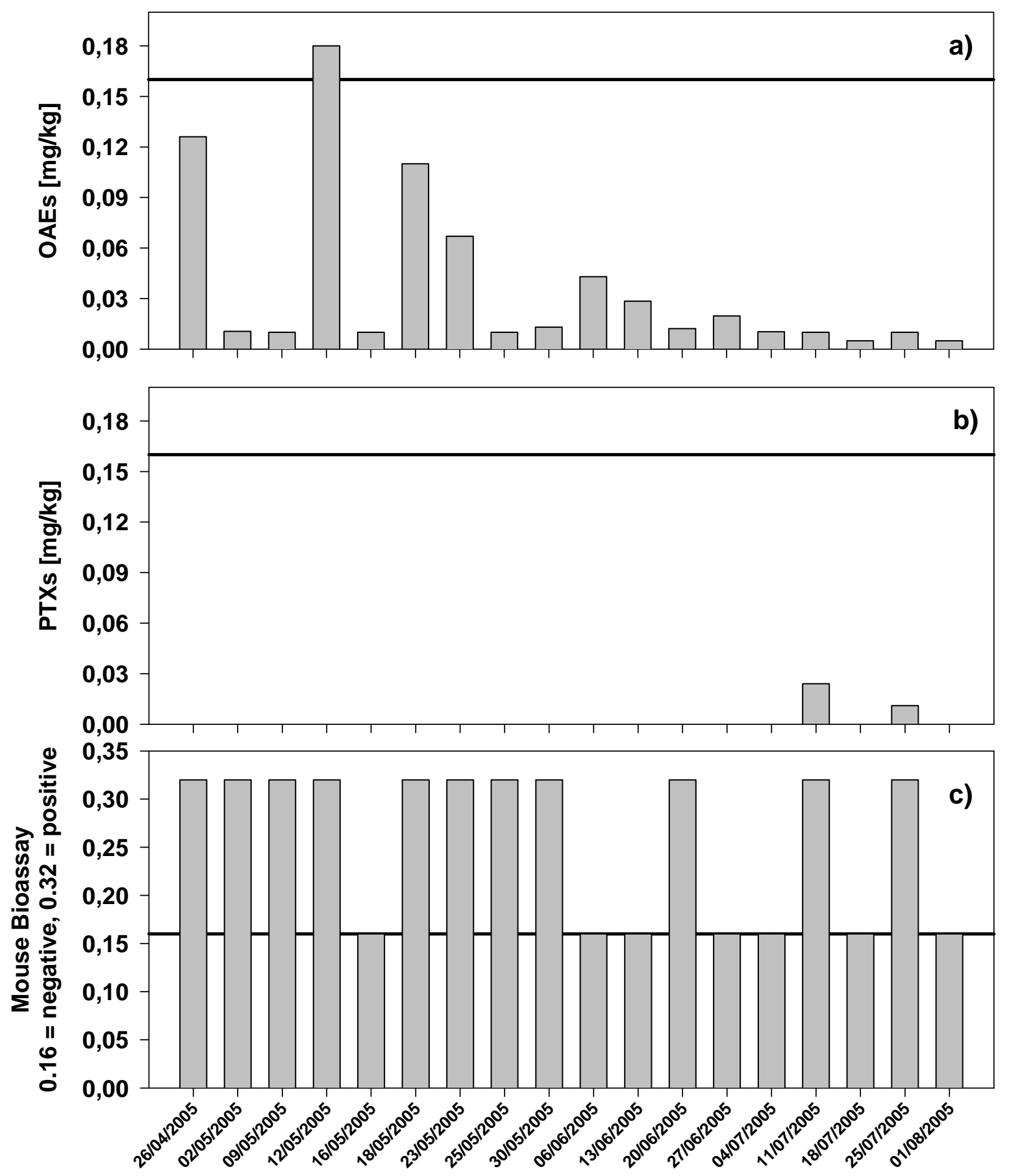

Figure 3

Figure 3. Temporal trends of okadaic acid group toxins, pectenotoxin group toxins and mouse bioassay results in oysters (C. gigas) from Arcachon, Bay of Biscay, French Atlantic coast from April 2005 to August 2005; a) okadaic acid equivalents (OAEs) and b) sum of pectenotoxins (PTX2 and PTX2sa), both determined by LC-MS (measured in hepatopancreas (HP) and expressed in whole shellfish flesh) and c) mouse bioassay (MBA) results for the same samples (measured in HP). The thick black line in each of the three graphs represents the regulatory limit in the EU at the time, i.e. $0.16 \mathrm{mg} / \mathrm{kg}$ for both OA- and PTX-group toxins. Arbitrarily, and for visualisation purposes only, MBA negative results are represented as $0.16 \mathrm{mg} / \mathrm{kg}$ values whereas MBA positives are represented as $0.32 \mathrm{mg} / \mathrm{kg}$ (Figure created from data available from 
Ifremer (REPHY, French national monitoring programme for micro-algae and phycotoxins) extracted 27/07/2009).
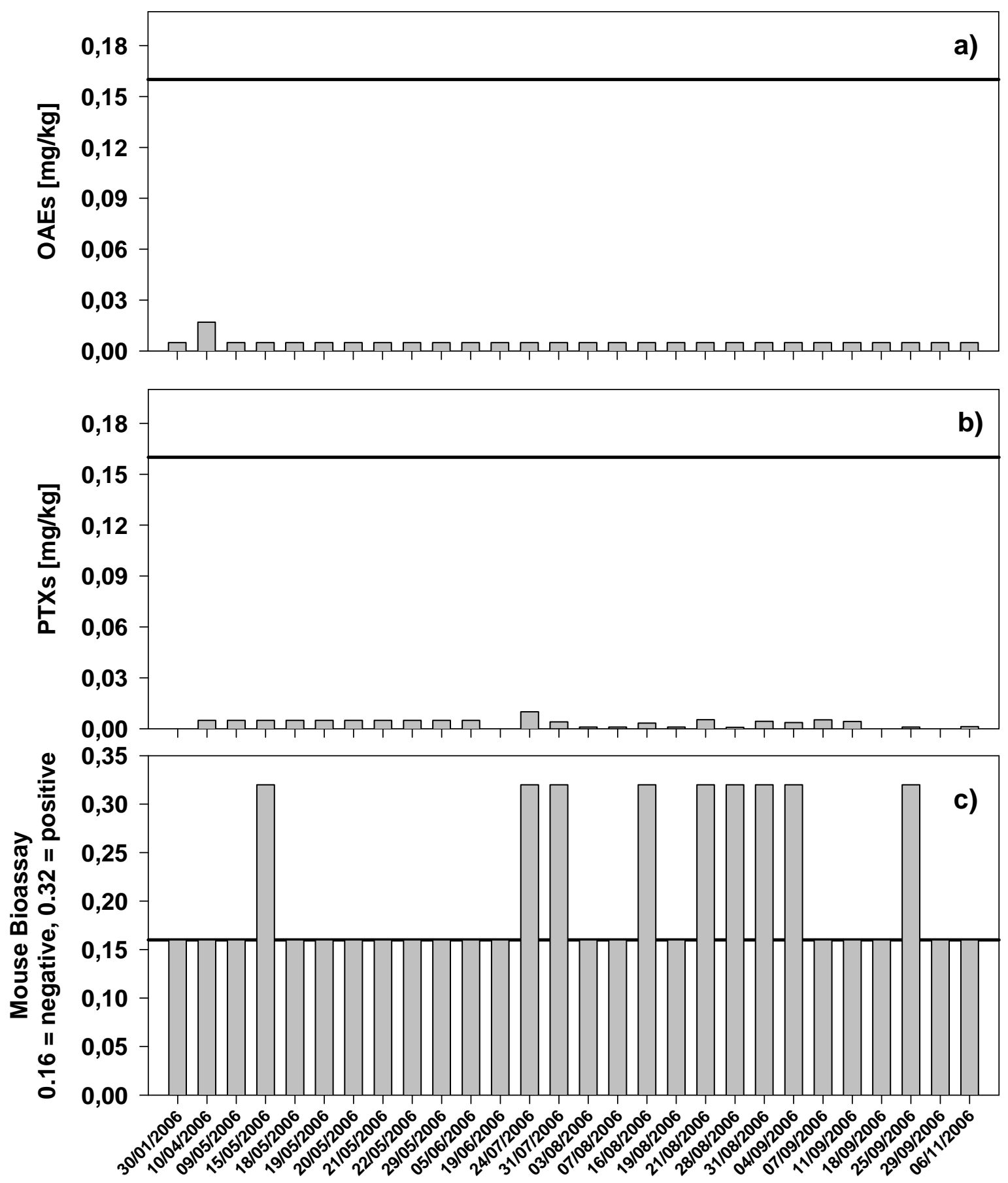

Figure 4. Temporal trends of okadaic acid group toxins, pectenotoxin group toxins and mouse bioassay results in oysters (C. gigas) from Arcachon, Bay of Biscay, French Atlantic coast from January 2006 to November 2006; a) okadaic acid equivalents (OAEs) and b) sum of pectenotoxins (PTX2 and PTX2sa), both determined by LC-MS (measured in hepatopancreas (HP) and expressed in whole shellfish flesh) c) mouse bioassay (MBA) results for the same samples (measured in HP). The thick black line in each of the three graphs represents the regulatory limit in the $\mathrm{EU}$ at the time, i.e. $0.16 \mathrm{mg} / \mathrm{kg}$ for both OA- and PTX-group toxins. Arbitrarily, and for visualisation purposes only, MBA negative results are represented as $0.16 \mathrm{mg} / \mathrm{kg}$ values whereas MBA positives are represented as $0.32 \mathrm{mg} / \mathrm{kg}$ (Figure created from data available from Ifremer (REPHY, French national monitoring programme for micro-algae and phycotoxins) extracted 27/07/2009). 